\title{
Nick Cowling
}

ROLLING THUNDER

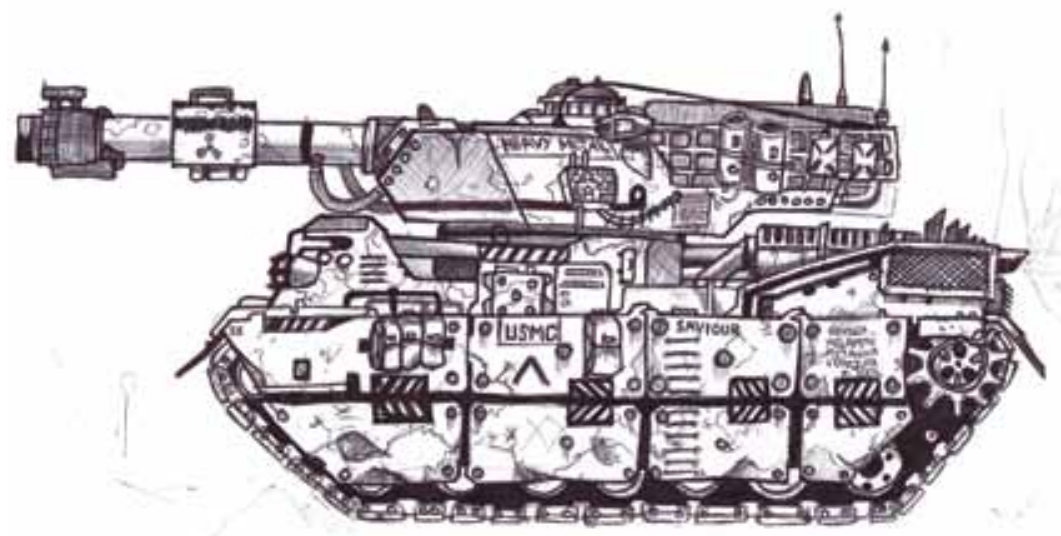

Io8 | Offset no. Io 